\title{
PENGARUH KUALITAS LAYANAN PENDIDIKAN TERHADAP KEPUASAN MAHASISWA PROGRAM STUDI MANAJEMEN FAKULTAS EKONOMI PADA UNIVERSITAS SWASTA DI BANDAR LAMPUNG
}

\author{
${ }^{1}$ Endang Siswati Prihastuti, ${ }^{2}$ Syahril Daud \\ ${ }^{1,2}$ Manajemen, Universitas Bandar Lampung \\ 1,2 Universitas Bandar Lampung \\ 1,2 Jl. ZA Pagar Alam No. 26 Labuhan Ratu \\ ${ }^{1}$ Email: endangsiswatiprihastuti@gmail.com \\ ${ }^{2}$ Email: syahrildaud@gmail.com
}

\begin{abstract}
ABSTRAK
Penelitian ini bertujuan untuk mengetahui gambaran kualitas layanan pendidikan terhadap kepuasan mahasiswa setelah mengikuti proses pendidikan, dan hasil penelitian ini digunakan untuk peningkatan kepuasan mahasiswa di masa yang akan datang. Populasi penelitian ini adalah mahasiswa program studi manajemen Fakultas Ekonomi Universitas Swasta di Bandar Lampung angkatan 2014, 2015 dan 2016. Penentuan besarnya sampel menggunakan tabel Isaac dan Michael dengan tingkat kepercayaan $5 \%$ dan menentukan anggota sampel dengan stratified random sampling. Teknik analisis data yang digunakan adalah Structural Equation Modelling (SEM), suatu analisis yang menggabungkan pendekatan analisis faktor faktor analisis, model structural (Stuctural Model), dan analisis jalur (Path Analysis). Variabel eksogen kualitas layanan pendidikan (X) terdr atas tangibles, reliability, responsiveness, assurance dan emphaty. Sedangkan Variabel endogen kepuasan (Y) adalah kognisi, afektif dan psikomotor.

Hasil penelitian menunjukkan bahwa 1) deskripsi kualitas layanan jasa pendidikan menurut persepsi mahasiswa secara keseluruhan termasuk katagori baik. Kualitas layanan variabel tangible, realiability, emphaty, assurance lebih penting daripada responsiveness, 2) deskripsi kepuasan mahasiswa setelah mengikuti proses pendidikan menurut persepsi mahasiswa secara keseluruhan termasuk katagori baik, 3) kualitas pelayanan jasa pendidikan berpengaruh signifikan terhadap kepuasan mahasiswa, 4) implikasi kebijakan mengindikasikan diperlukannya perbaikan dalam hal ; a) kebersihan ruang kuliah, b) menyelesaikan keluhan mahasiswa, c) penanganan administrasi dengan cepat, d) perhatian dengan masa pendidikan yang terkontrol, e) keramahan karyawan dalam memberikan pelayanan.
\end{abstract}

Kata kunci: kualitas layanan/jasa pendidikan, kepuasan mahasiswa.

\begin{abstract}
This study aims to determine the description of the quality of educational services to student satisfaction after attending the educational process, and the results of this study are used to increase student satisfaction in the future. The population of this research is the management study program students at the Faculty of Economics, Private Universities in Bandar Lampung in 2014, 2015 and 2016. Determination of the size of the sample uses the Isaac and Michael tables with a 5\% confidence level and determines the sample members with stratified random sampling. The data analysis technique used is Structural Equation Modeling (SEM), an analysis that combines factor analysis approaches, structural models (Structural Model), and path analysis (Path Analysis). The exogenous variable education
\end{abstract}


service quality $(\mathrm{X})$ consists of tangibles, reliability, responsiveness, assurance and empathy. Whereas endogenous variables of satisfaction (Y) are cognition, affective and psychomotor.

The results showed that 1) a description of the quality of educational services according to students' perceptions as a whole including good categories.variable service quality Tangible, reliability, empathy, assurance is more important than responsiveness, 2) description of student satisfaction after attending the education process according to overall student perceptions including good categories, 3) quality of education services has a significant effect on student satisfaction, 4) policy implications indicate the need for improvement in terms of; a) cleanliness of the lecture room, b) resolve student complaints, c) handle administration quickly, d) pay attention to a controlled period of education, e) hospitality of employees in providing services.

Keywords: quality of education services / services, student satisfaction.

\section{PENDAHULUAN}

Pada era globalisasi sekarang ini persaingan baik dibidang ekonomi/bisnis maupun dibidang pendidikan sangatlah ketat dan hal tersebut pasti akan terjadi yang merupakan tantangan untuk dihadapi. Perkembangan ilmu pengetahuan dan teknologi yang sangat cepat dari waktu kewaktu serta kebutuhan masyarakat yang semakin meningkat, maka pengelola perguruan tinggi dituntut untuk meningkatkan kualitas layanan/jasa pendidikan secara berkelanjutan sesuai dengan tuntutan masyarakat. Perguruan tinggi menurut UndangUndang Pendidikan Nomor: 12 tahun 2012 tentang Pendidikan adalah satuan pendidikan yang menyelenggarakan Pendidikan Tinggi. Menurut Undang-Undang Pendidikan Nomor: 12 tahun 2012 tentang Pendidikan Tinggi dinyatakan bahwa pendidikan tinggi adalah jenjang pendidikan setelah pendidikan menengah yang mencakup program diploma, program sarjana, program magister, program doktor, dan program profesi, serta program spesialis, yang diselenggarakan oleh Perguruan Tinggi berdasarkan kebudayaan bangsa Indonesia (Aziz, 2016:21). Menurut Tampubolon (1997), Perguruan Tinggi merupakan sebuah lembaga pelayanan jasa pendidikan yang dalam pelaksanaan kegiatannya harus selalu berusaha memenuhi needs (kebutuhan), wants (keinginan), dan expectation (harapan) pelanggan. Perguruan Tinggi adalah merupakan industri jasa yang mempunyai pelanggan yaitu; sekelompok orang atau masyarakat yang mempunyai kepentingan baik langsung maupun tidak langsung atas pelaksanaan pendidikan maupun hasil-hasilnya, meliputi mahasiswa, orang tua mahasiswa, masyarakat, dunia kerja/pasar kerja, perusahaan, dan pemerintah. Berbagai kepentingan yang berbeda dari pelanggan tersebut harus menjadi acuan utama dalam merencanakan maupun melaksanakan kualitas layanan jasa pendidikan dan mutu/ kualitas hasil pendidikan. 
Menurut Tjiptono \& Chandra (2012:75) dalam kasus pemasaran jasa, dimensi kualitas yang paling sering dijadikan acuan adalah: reliabilitas (reliability), responsivitas (responsiveness), jaminan (assurance), empati (emphaty), bukti phisik (tangibles). Padadasarnya terdapat pengaruh yang kuat kualitas layanan jasa terhadap kepuasan konsumen/pelanggan. Dalam konteks pendidikan kepuasan pelanggan tergantung hasil pendidikan yang cenderung multidimensi yang selalu dikaitkan dengan kemampuan kognisi, afeksi dan psikomotorik. Walaupun dalam layanan jasa dalam proses pembelajaran tujuannya adalah prestasi belajar dalam aspek kognisi, namun aspek afektif dan psikomotorik sangat diperlukan. Implikasinya, baik buruknya kualitas layanan jasa tergantung kemampuan penyedia jasa dalam memenuhi kepuasan pelanggannya secara konsisten. Salah satu strategi yang dapat digunakan agar program studi manajemen tetap eksis bukan karena brand yang kuat tetapi bagaimana pelayanan jasa dikemas sedemikian rupa sehingga hasil pendidikan mampu memuaskan mahasiswa, orang tua, pemerintah, dunia kerja, dan lembaga-lembaga lainnya. Oleh karena itu kualitas perguruan tinggi dituntut tidak hanya dalam bentuk layanan fisik saja, tetapi juga kualitas layanan yang profesional terhadap mahasiswa sehingga merasa puas dan loyal menyampaikan kepada rekannya untuk kuliah di program studi ini. Strategi yang dapat digunakan adalah dengan merancang layanan jasa prima yang didukung oleh tenaga pengajar yang kompeten di bidangnya, layanan administrasi yang cepat dan ramah serta didukung oleh fasilitas sarana prasarana yang memadai, biaya pendidikan yang relatif murah, proses pendidikan yang tepat waktu dan lingkungan yang kondusif. Oleh karena itu perlu dilakukan penelitian tentang kualitas layanan jasa pendidikan tingkat program studi manajemen dan tingkat kepuasan mahasiswa terhadap hasil pendidikan. Hasil penelitian dapat menjadi dasar untuk meningkatkan layanan jasa pendidikan, sehingga kepuasan mahasiswa meningkat dan pada waktunya loyal untuk merekomendasikan kepada rekan-rekannya yang lain untuk kuliah di program studi manajemen.

Pelanggan khususnya mahasiswa selalu memperhitungkan nilai hasil pendidikan yang diperoleh ketika masuk perguruan tinggi (nilai pelanggan). Total nilai pelanggan bukan hanya terdiri atas nilai produk pendidikan (product value) saja, melainkan juga kualitas layanan (service value) selama mengikuti proses pembelajaran. Tujuan penelitian ini untuk mengetahui diskripsi kualitas layanan jasa pendidikan pada program studi manajemen, serta untuk mengetahui diskripsi tingkat kepuasan mahasiswa terhadap $\underline{\text { hasil pendidikan dan untuk menganalisis besarnya pengaruh kualitas layanan jasa }}$ 
pendidikan pada program studi manajemen terhadap kepuasan mahasiswa. Sedangkan manfaat hasil penelitian ini merupakan evaluasi kualitas layanan program studi manajemen dan tingkat kepuasan mahasiswa dan hasil penelitian ini dapat digunakan sebagai bahan rekomendasi untuk memperbaiki kualitas layanan jasa pendidikan pada program studi manajemen sehingga dapat meningkatkan kepuasan mahasiswa terhadap hasil pendidikan.

\section{TINJAUAN PUSTAKA}

Dalam dunia bisnis atau industri yang memproduksi produk atau jasa mempunyai konsumen yang sering disebut dengan pelanggan. Pelanggan merupakan konsumen sebagai pembeli ataupun pengguna jasa yang melakukan kegiatan pembelian atau penggunaan jasa secara berulang yang dikarenakan memperoleh kepuasan dari produk atau jasa yang diterimanya. Demikian halnya dengan industri jasa pendidikan perguruan tinggi mempunyai pelanggan. Pelanggan pendidikan perguruan tinggi dapat dibedakan sebagai berikut: a) Pelanggan internal, yaitu pengelola perguruan tinggi (pimpinan, tenaga pendidik, tenaga administrasi dan tenaga teknisi), b) Pelanggan eksternal primer adalah mahasiswa, c) Pelanggan sekunder adalah orang tua, masyarakat, pemerintah, lembaga sponsor, lingkungan, d) Pelanggan tersier adalah pengguna lulusan atau dunia kerja (perusahaan, organisasi, pemerintah, dan lain-lain). Pelanggan merupakan salah satu faktor yang penting dalam memberikan kontribusi pendapatan baik pada perusahaan bisnis maupun pada dunia pendidikan perguruan tinggi negeri, terlebih bagi perguruan tinggi swasta. Perusahaan bisnis maupun industri jasa pendidikan perguruan tinggi negeri dan swasta tidak akan dapat melakukan kegiatan tanpa pelanggan.

\section{Kualitas Layanan Jasa Pendidikan}

Kualitas layanan atau jasa suatu perusahaan bisnis, termasuk layanan jasa pendidikan akan dinilai oleh pelanggan. Menurut Tjiptono \& Chandra (2012:75) menyebutkan bahwa kualitas layanan jasa dapat diukur dengan menggunakan lima dimensi yaitu: 1) Bukti langsung (tangibles),meliputi fasilitas fisik, perlengkapan, pegawai dan sarana komunikasi, 2) Reliabilitas (reliability), kemampuan untuk memberikan pelayanan yang dijanjikan dengan segera, akurat dan memuaskan, 3) Daya tanggap (responsiveness), yaitu keinginan untuk membantu para konsumen dan memberikan pelayanan sebaik mungkin, 4) Jaminan/keyakinan (assurance), yaitu pengetahuan dan kesopansantunan para pegawai perusahaan serta kemampuan menumbuhkan rasa percaya para konsumennya kepada perusahaan, 5) Empati (empathy),meliputi kemudahan melakukan hubungan, komunikasi yang baik, perhatian pribadi dan memahami kebutuhan para pelanggan. Kualitas memiliki 
hubungan yang erat dengan kepuasan pelanggan. Goetsch dan Davis menyatakan bahwa ; Kualitas merupakan suatu kondisi dinamis yang berhubungan dengan produk, jasa, manusia, proses dan lingkungan yang memenuhi atau melebihi harapan (Tjiptono \& Diana, 2003:4). Sehingga definisi kualitas pelayanan dapat diartikan sebagai upaya pemenuhan kebutuhan dan keinginan konsumen serta ketepatan penyampaiannya dalam mengimbangi harapan konsumen. Kualitas layanan mencerminkan perbandingan antara tingkat layanan yang disampaikan perusahaan dibandingkan ekspektasi pelanggan. Bahwa kualitas pelayanan sebagai penilaian pelanggan atas keunggulan atau keistimewaan suatu produk atau layanan secara menyeluruh. Kualitas pelayanan dapat diketahui dengan cara membandingkan persepsi para konsumen atas pelayanan yang diterima dengan pelayanan yang sesungguhnya konsumen harapkan terhadap atribut-atribut pelayanan suatu perusahaan. Menurut Tjiptono \& Chandra, (2012:77), kualitas layanan diwujudkan melalui pemenuhan kebutuhan dan keinginan pelanggan serta ketepatan penyampaiannya dalam mengimbangi atau melampaui harapan pelanggan. Harapan pelanggan bisa berupa tiga standar ; (1) Will expectation, yaitu tingkat kinerja yang diantisipasi atau diperkirakan konsumen akan diterimanya, berdasarkan semua informasi yang diketahuinya; (2) Should expectation, yaitu tingkat kinerja yang dianggap sudah sepantasnya diterima konsumen; (3) Ideal expectation, yaitu tingkat kinerja optimum atau terbaik yang diharapkan dapat diterima konsumen.

\section{Karakteristik Layanan Jasa Pendidikan}

Kotler \& Amstrong (2008:266) mendifinisikan jasa sebagai"semua kegiatan atau manfaat yang dapat ditawarkan suatu pihak kepada pihak lain, yang pada dasarnya tak berwujud (intangible) dan tidak menghasilkan kepemilikan sesuatu". Dalam kaitannya dengan layanan jasa pendidikan berikut digambarkan karakteristik jasa pendidikan yang dikutip dari pernyataan Bitner dkk (1993) serta Tadepalli \& Hayes (2000), sebagai berikut (Wijaya, 2012:6-7): 1) Tidak berwujud (intangibility), jasa pendidikan bersifat kasat mata sehingga menyebabkan pelanggan jasa pendidikan tidak dapat melihat, mencium, mendengar, meraba, dan merasakan hasil keluaran pendidikan sebelum mereka mengonsumsinya menjadi subsistem sekolah (perguruan tinggi), 2) Tidak dapat dipisahkan (inseparability), jasa pendidikan tidak dapat dipisahkan dari sumbernya, yaitu sekolah (perguruan tinggi) yang berarti jasa pendidikan dihasilkan dan dikonsumsi secara serempak pada waktu yang bersamaan. Jika siswa/mahasiswa mengonsumsi jasa pendidikan, mereka berhadapan langsung dengan penyedia jasa pendidikan, 3) Beraneka ragam (variability), jasa pendidikan bersifat variabel karena merupakan output tidak 
standar (nonstandardized output), yaitu memiliki banyak variasi, bentuk kualitas, dan jenis yang bergantung pada siapa, kapan, dan di mana jasa pendidikan dihasilkan, 4) Tidak tahan lama (perishability), jasa pendidikan merupakan komoditas yang tidak tahan lama dan tidak dapat disimpan. Sifat tidak tahan lama berarti jasa pendidikan tidak dapat dimasukkan ke gudang atau tidak dapat dijadikan sebagai persediaan, 5) Kepemilikan (ownership), mahasiswa memperoleh hak untuk mengakses perpustakaan ketika menunjukkan kartu perpustakaan kepada petugas perpustakaan.

Menurut Lupiyoadi \& Hamdani (Wijaya, 2012:7) dalam membahas karakteristik jasa pendidikan perlunya memperhatikan hal-hal sebagai berikut : 1) Pendidikan adalah jasa murni, di mana proses penyampaian jasa pendidikan yang dilakukan telah didukung oleh peralatan kerja atau sarana pendukung pendidikan, seperti ruang kelas, kursi, meja, buku, dan sebagainya, 2) Jasa pendidikan yang disampaikan memerlukan kehadiran pelanggan jasa pendidikan (mahasiswa), di mana mahasiswa mendatangi perguruan tinggi untuk mendapatkan jasa pendidikan yang dinginkan (meskipun dalam perkembangannya ada perguruan tinggi yang menawarkan program pembelajaran jarak jauh), 3) Penerima jasa pendidikan adalah orang. Jasa pendidikan adalah jasa yang berbasis orang, atau disebut sistim kontak tinggi atau sistim hubungan yang tinggi (high contact system) di mana hubungan antara penyedia jasa dan pelanggannya tinggi. Pelanggan dan penyedia jasa pendidikan terus menerus berinteraksi selama proses penyampaian jasa pendidikan berlangsung. Dengan kata lain, untuk menerima jasa pendidikan, pelanggan jasa pendidikan harus menjadi bagian dari sistim jasa pendidikan, 4) Hubungan antara penyedia jasa pendidikan dan pelanggan jasa pendidikan berdasarkan hubungan keanggotaan (member relationship), dimana pelanggan jasa pendidikan telah menjadi anggota dari perguruan tinggi tertentu.

\section{Kepuasan Pelanggan}

Menurut Kotler \& Keller (Tjiptono, 2014:354) menyatakan bahwa kepuasan pelanggan adalah tingkat perasaan seseorang setelah membandingkan kinerja (atau hasil) yang ia rasakan dibandingkan dengan harapannya. Bagi bisnis, kepuasan dipandang sebagai salah satu dimensi kinerja pasar. Peningkatan kepuasan pelanggan berpotensi mengarah pada pertumbuhan penjualan jangka panjang dan jangka pendek, serta pangsa pasar sebagai hasil pembelian ulang (Tjiptono \& Chandra, 2012:55). Secara umum, kepuasan adalah perasaan senang atau kecewa seseorang yang muncul setelah membandingkan kinerja (hasil) produk yang dipikirkan terhadap kinerja (atau hasil) yang diharapkan. Jika kinerja berada dibawah harapan, pelanggan tidak puas. Jika 
kinerja memenuhi harapan, pelanggan puas. Jika kinerja melebihi harapan, pelanggan amat puas atau senang (Kotler \& Keller, 2007:177). Beberapa konsep teori kepuasan pelanggan sangat beragam dan semakin berkembang. Hal tersebut adalah berdasarkan perspektif psikologi dari kepuasan pelanggan, dan berdasarkan perspektif Total Quality Management. Berdasarkan perspektif psikologi, terdapat dimensi untuk mengevaluasi kepuasan pelanggan/mahasiswa setelah mengalami proses pendidikan yaitu: a) Dimensi kognisi; mencakup pengetahuan, penguasaan dan pemahaman mahasiswa setelah mengikuti proses pembelajaran, b) Dimensi afeksi, mencakup; sikap, aspirasi, perasaan, dorongan dan nilai-nilai, c) Dimensi psikomotor adalah; keterampilan fungsional, meliputi keterampilan teknik, sosial, manajerial, intelektual, emosional dan spiritual.

\section{Kerangka Berpikir}

Berdasarkan latar belakang permasalahan dan tinjauan pustaka, dapat dibuat kerangka berpikir sebagai berikut:

Gambar 1. Kerangka Berpikir Pengaruh Layanan Pendidikan Terhadap Kepuasan Mahasiswa Program Studi Manajemen Fakultas Ekonomi Pada Universitas Swasta di Bandar Lampung

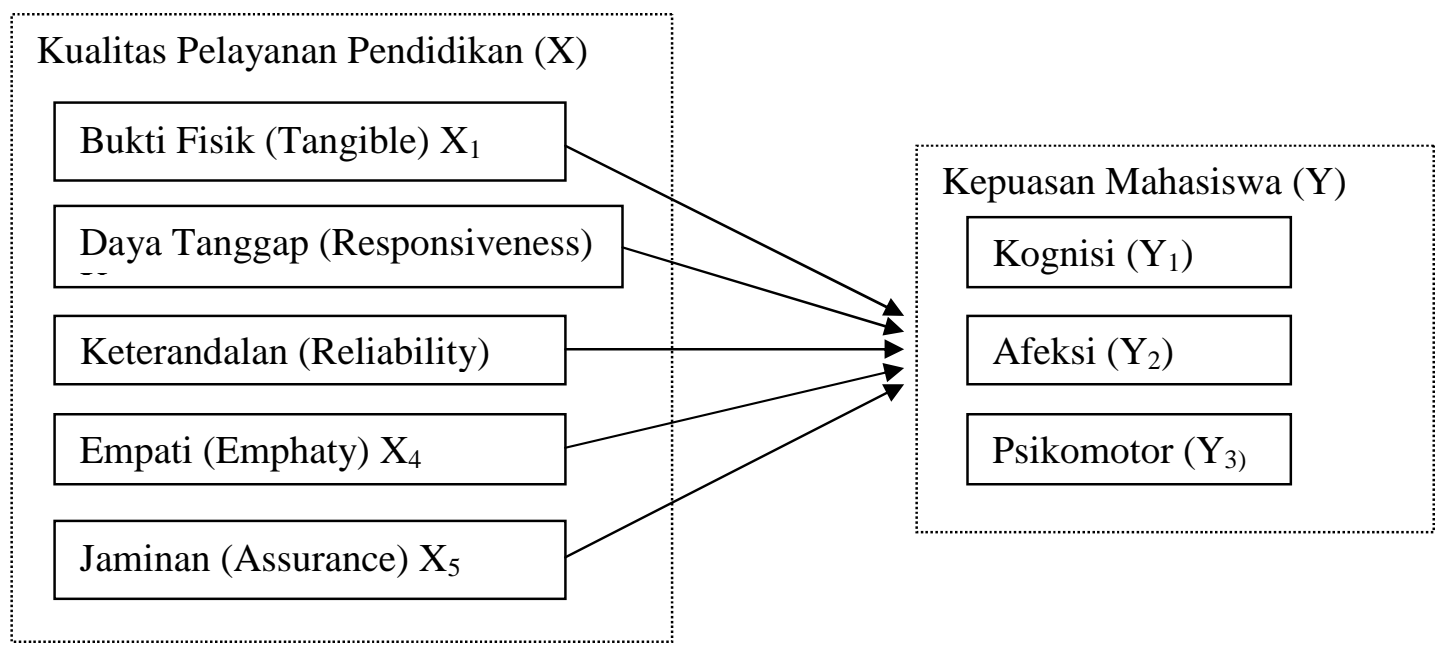

Keterangan :

$\mathrm{X}=$ Kualitas Pelayanan Pendidikan $\quad \mathrm{Y}=$ Kepuasan Mahasiswa

$\mathrm{X}_{1}$ : Tangible

$\mathrm{X}_{2}:$ Responsiveness

$\mathrm{Y}_{1}:$ Kognisi

$\mathrm{X}_{3}:$ Reliability

$\mathrm{Y}_{2}:$ Afeksi

$\mathrm{X}_{4}:$ Emphaty

$\mathrm{X}_{5}$ : Assurance

Dari kerangka berpikir tersebut digambarkan dimensi kualitas pelayanan jasa pendidikan yang terdiri dari: tangibles $\left(X_{1}\right)$, responsiveness $\left(X_{2}\right)$, reliability $\left(X_{3}\right)$, emphaty 
$\left(X_{4}\right)$ dan assurance $\left(X_{5}\right)$ secara bersama-sama maupun secara parsial mempunyai pengaruh terhadap kepuasan mahasiswa Program Studi Manajemen Fakultas Ekonomi pada Universitas Swasta di Bandar Lampung. Dimensi kepuasan mahasiswa terdiri dari; kognisi $\left(\mathrm{Y}_{1}\right)$, afeksi $\left(\mathrm{Y}_{2}\right)$ dan psikomotor $\left(\mathrm{Y}_{3}\right)$

\section{METODE PENELITIAN}

\section{Jenis Penelitian}

Jenis penelitian yang digunakan adalah explanatory research, yaitu penelitian bertujuan untuk menguji suatu teori atau hipotesis guna memperkuat atau bahkan menolak teori atau hipotesis penelitian yang sudah ada sebelumnya. Dalam penelitian ini, yang akan dianalisis adalah pengaruh kualitas pelayanan yang terdiri dari tangible, responsiveness, reliability, emphaty, assurance terhadap kepuasan mahasiswa, dimana kualitas pelayanan merupakan variabel yang memengaruhi (variabel independen/variabel eksogen), sedangkan kepuasan mahasiswa merupakan variabel yang dipengaruhi (variabel dependen/variabel endogen). Populasi dalam penelitian ini adalah mahasiswa Program Studi Manajemen pada 3 (tiga) Universitas Swasta di Bandar Lampung, yaitu Fakultas Ekonomi dan Bisnis Universitas Bandar Lampung (UBL), Fakultas Ekonomi Universitas Sang Bumi Ruwa Jurai/Saburai (USBRJ), dan Fakultas Ekonomi Universitas Malahayati (UNMAL).

Instrumen penelitian ini meliputi daftar pertanyaan/kuisioner kualitas pelayanan dan kepuasan mahasiswa. Penyusunan pertanyaan/kuisioner kualitas pelayanan berdasarkan pada aspek-aspek kualitas pelayanan yang dikemukakan oleh Parasuraman, at.al (Tjiptono \& Chandra, 2012:75) menyebutkan bahwa kualitas layanan jasa dapat diukur dengan menggunakan lima dimensi SERVQUAL yang dapat diterapkan dalam dunia pendidikan yaitu: 1) Bukti langsung (tangibles), meliputi fasilitas fisik, perlengkapan, pegawai dan sarana komunikasi, 2) Reliabilitas (reliability), kemampuan untuk memberikan pelayanan yang dijanjikan dengan segera, akurat dan memuaskan, 3) Daya tanggap (responsiveness), yaitu keinginan untuk membantu para konsumen dan memberikan pelayanan sebaik mungkin, 4) Jaminan/keyakinan (assurance),yaitu pengetahuan dan kesopansantunan para pegawai perusahaan serta kemampuan menumbuhkan rasa percaya para konsumennya kepada perusahaan, 5) Empati (empathy),meliputi kemudahan melakukan hubungan, komunikasi yang baik, perhatian pribadi dan memahami kebutuhan para pelanggan.

Mengukur tingkat kepuasan mahasiswa berdasarkan perspektif psikologi, terdapat dimensi untuk mengevaluasi kepuasan mahasiswa setelah mengalami proses pendidikan 
yaitu: 1) Dimensi kognisi; mencakup pengetahuan, penguasaan dan pemahaman mahasiswa setelah mengikuti proses pembelajaran, 2) Dimensi afeksi, mencakup; sikap, aspirasi, perasaan, dorongan dan nilai-nilai, 3) Dimensi psikomotor adalah keterampilan fungsional, meliputi keterampilan teknik, sosial, manajerial, intelektual, emosional dan spiritual.

\section{Teknik Analisis}

Teknik analisis data yang digunakan adalah permodelan persamaan structural (Structural Equation Modelling). Permodelan persamaan structural (SEM) dapat dideskripsikan sebagai suatu analisis yang menggabungkan pendekatan analisis faktor model structural (Stuctural Model), dan analisis jalur (Path Analysis). Dengan demikian, didalam analisis permodelan persamaan structural (SEM) dapat dilakukan tiga macam kegiatan secara serentak, yaitu pengecekan validitas dan reliabilitas instrument (berkaitan dengan analisis faktor konfirmatori), pengujian model hubungan antara variabel (berkaitan dengan analisis jalur), dan kegiatan untuk mendapatkan suatu model yang cocok untuk prediksi (berkaitan dengan analisis regresi atau analisis model structural)(Sugiyono, 2012:323).

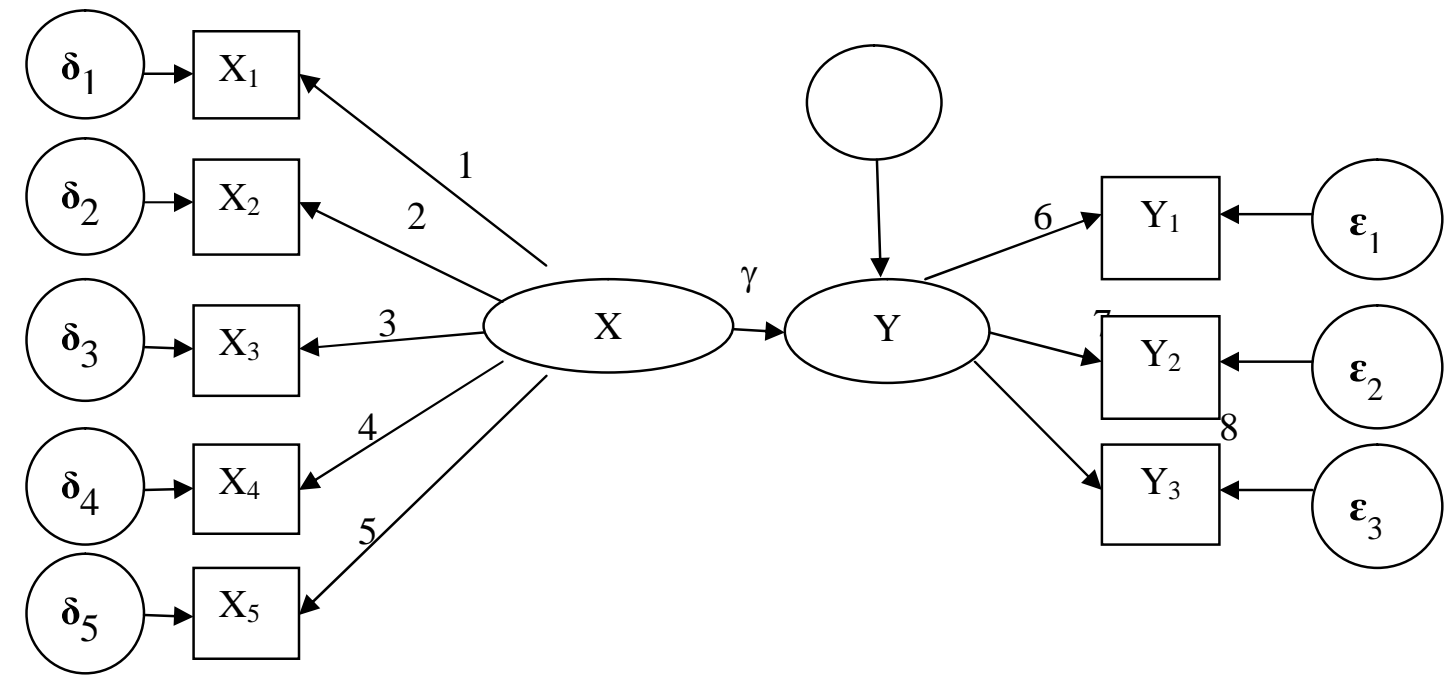

Keterangan :

Gambar 2. Full Model Structural.

$$
\begin{aligned}
& \mathrm{X}= \text { Kualitas Layanan } \\
& \mathrm{X}_{1}: \text { Tangible } \\
& \mathrm{X}_{2}: \text { Responsiveness } \\
& \mathrm{X}_{3}: \text { Reliability } \\
& \mathrm{X}_{4}: \text { Emphaty } \\
& \mathrm{X}_{5}: \text { Assurance }
\end{aligned}
$$

$$
\begin{gathered}
\mathrm{Y}=\text { Kepuasan Mahasiswa } \\
\mathrm{Y}_{1}: \text { Kognisi } \\
\mathrm{Y}_{2}: \text { Afeksi } \\
\mathrm{Y}_{3}: \text { Psikomotor }
\end{gathered}
$$


Dari gambar full model structural tersebut di atas maka diperoleh persamaan sebagai berikut:

Keterangan:

$$
\eta=\gamma \xi+\zeta
$$

$\eta=$ Eta, variabel laten $\mathrm{Y}$

$\xi=$ Ksi, variabel laten $\mathrm{X}$

$\lambda=$ Lamnda (kecil), loading faktor

$\gamma=$ Gama (kecil), koefisien pengaruh variabel eksogen terhadap variabel endogen

$\zeta=$ Zeta (kecil), galat model

$\varepsilon=$ Epsilon (kecil), galat pengukuran pada variabel manifest untuk variabel laten $\mathrm{Y}$

$\delta=$ Delta (kecil), galat pengukuran pada variabel manifest untuk variabel laten $\mathrm{X}$

Untuk memperoleh model yang baik atau goodness of fit statistics maka harus memenuhi seperti terlihat pada tabel berikut ini: (Sugiyono, 2012:346)

Tabel 1. Goodness of Fit Statistics

\begin{tabular}{|c|l|c|}
\hline No & Statistik & Kriteria 'Fit' \\
\hline 1 & $\mathrm{X}^{2}=$ Chi squares & $\mathrm{P}>0,05$ \\
2 & Root mean square error of approximation (RMSEA). & $<0,08$ \\
3 & Goodness-of-fit-index (GFI) & $>0,9$ \\
4 & Adjusted goodness-of-fit-index (AGFI) & $>0,9$ \\
5 & Parsimonius goodness -of-fit- index (PGFI) & $>0,9$ \\
6 & Normed fit index (NFI) & $>0,9$ \\
7 & Parsimonius normed fit index (PNFI) & $>0,9$ \\
8 & Comparative fit index (CFI) & $>0,9$ \\
9 & Non-normed fit index (NNFI) & $>0,9$ \\
10 & Incremental fit index (IFI) & $>0,9$ \\
11 & Relative fit index (RFI) & $>0.9$ \\
12 & Standardized root mean square residual (SRMR) & $<0,05$ \\
13 & Critical N (CN) & $\mathrm{N}>200$ \\
\hline
\end{tabular}

\section{Populasi dan Sampel}

Populasi Penelitian

Sebagai populasi dalam penelitian ini adalah mahasiswa Program Studi Manajemen Fakultas Ekonomi dan Bisnis pada Universitas Bandar Lampung (UBL), Universitas Sang Bumi Ruwa Jurai/Saburai (USBRJ), dan Fakultas Ekonomi Universitas Malahayati (UNMAL), yang terdaftar pada tahun akademik 2014, 2015, dan 2016 sebagai berikut:

Tabel 2. Jumlah Populasi

\begin{tabular}{|c|l|c|c|c|c|}
\hline No & Obyek Penelitian & $\begin{array}{c}\text { Angkatan } \\
2014\end{array}$ & $\begin{array}{c}\text { Angkatan } \\
2015\end{array}$ & $\begin{array}{c}\text { Angkatan } \\
2016\end{array}$ & Jumlah \\
\hline 1 & $\begin{array}{l}\text { Universitas } \\
\text { Bandar Lampung } \\
\text { (N1) }\end{array}$ & 145 & 160 & 181 & 486 \\
2 & $\begin{array}{l}\text { Universitas } \\
\text { Saburai (N2) }\end{array}$ & 159 & 221 & 341 & 721 \\
3 & $\begin{array}{l}\text { Universitas } \\
\text { Malahayati (N3) }\end{array}$ & Total Populasi & 11 & 4 & 37 \\
\hline
\end{tabular}


Sumber data: Universitas Bandar Lampung, Universitas Saburai, Universitas

\section{Penentuan Sampel} Malahayati 2017.

Ukuran sampel mengacu pada tabel penentuan jumlah sampel dari populasi tertentu yang dikembangkan dari Isaac dan Michael (Sugiyono, 2001:81) dengan taraf kesalahan $5 \%$.

Pengalokasian sampel digunakan metode alokasi proporsional dengan rumus:

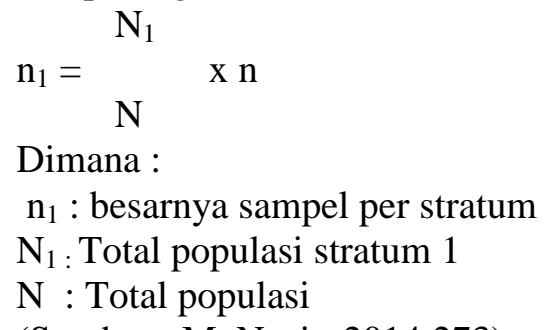

(Sumber : M. Nazir, 2014:273)

tTabel 3. Jumlah Sampel

\begin{tabular}{|c|l|c|c|c|c|}
\hline No & Obyek Penelitian & $\begin{array}{c}\text { Angkatan } \\
2014\end{array}$ & $\begin{array}{c}\text { Angkatan } \\
2015\end{array}$ & $\begin{array}{c}\text { Angkatan } \\
2016\end{array}$ & Jumlah \\
\hline 1 & $\begin{array}{l}\text { Universitas } \\
\text { Bandar Lampung } \\
\left(\mathrm{n}_{1}\right)\end{array}$ & 32 & 35 & 39 & 106 \\
2 & $\begin{array}{l}\text { Universitas } \\
\text { Saburai }\left(\mathrm{n}_{2}\right)\end{array}$ & 35 & 48 & 75 & 158 \\
3 & $\begin{array}{l}\text { Universitas } \\
\text { Malahayati }\left(\mathrm{n}_{3}\right)\end{array}$ & 5 & 2 & 1 & 8 \\
& Jumlah Sampel & & & 272 \\
\hline
\end{tabular}

Sumber : Data diolah 2017.

Teknik sampling yang digunakan Stratified Random Sampling. Stratified Random Sampling adalah sampel yang ditarik dengan memisahkan elemen-elemen populasi dalam kelompok-kelompok yang tidak overlapping yang disebut strata, dan kemudian memilih sebuah sampel secara random dari tiap stratum (Nazir, 2014:258).

\section{HASIL DAN PEMBAHASAN}

\section{Analisis Deskripsi Tanggapan Responden.}

Analisis deskripsi digunakan untuk mengetahui tanggapan responden terhadap masing-masing variabel laten dan indikator. Kuisioner yang diberikan kepada responden mengacu pada kriteria skor normatif, yaitu sangat tidak baik (STB), kurang baik (KB), cukup baik (CB), baik (B), dan baik sekali (BS). Penjabaran data dilakukan dengan memberi skor terhadap jawaban responden yang diperoleh melalui penyebaran kuesioner. Berdasarkan pada kategori skor normatif tersebut, maka masing-masing variabel penelitian dapat dijelaskan sebagai berikut:

Variabel Laten Kualitas Layanan Pendidikan 
Untuk mengetahui kualitas dari suatu layanan dapat dilihat dari berbagai dimensi. Pada sebuah organisasi pendidikan tinggi, dimensi kualitas layanan pendidikan yang dialami oleh mahasiswa sebagai berikut : bukti fisik (Tangible), daya tanggap (Responsiveness), keterandalan (Reliability), empati (Emphaty), dan jaminan (Assurance).

Tabel 4. Tanggapan Responden Terhadap Variabel Bukti Fisik (Tangible).

\begin{tabular}{|c|l|c|c|c|c|c|c|c|}
\hline \multirow{2}{*}{ No } & \multicolumn{1}{|c|}{ Indikator } & \multirow{2}{*}{$\begin{array}{c}\text { Simbo } \\
1\end{array}$} & $\begin{array}{c}\text { ST } \\
\text { B }\end{array}$ & KB & CB & B & BS & \multirow{2}{*}{ Rata-Rata } \\
\hline 1 & $\begin{array}{l}\text { Kenyamanan ruang } \\
\text { kuliah }\end{array}$ & X11 & 1 & 11 & 53 & $\begin{array}{c}15 \\
0\end{array}$ & 34 & 3,82 \\
\hline 2 & Fasilitas ruang kuliah & X12 & 2 & 7 & 46 & $\begin{array}{c}15 \\
8\end{array}$ & 36 & 3,88 \\
\hline 3 & Kebersihan ruang kuliah & $\mathrm{X} 13$ & 0 & 13 & 67 & $\begin{array}{c}13 \\
0\end{array}$ & 39 & 3,78 \\
\hline 4 & Kerapihan ruang kuliah & $\mathrm{X} 14$ & 1 & 6 & 45 & $\begin{array}{c}13 \\
5\end{array}$ & 62 & 4,01 \\
\hline 5 & $\begin{array}{l}\text { Kebersihan } \\
\text { mandi }\end{array}$ & $\mathrm{X} 15$ & 0 & 3 & 50 & $\begin{array}{c}14 \\
6\end{array}$ & 50 & 3,98 \\
\hline 6 & Kerapihan karyawan & $\mathrm{X} 16$ & 0 & 5 & 41 & $\begin{array}{c}15 \\
9\end{array}$ & 44 & 3,97 \\
\hline 7 & Pengaturan areal parkir & $\mathrm{X} 17$ & 0 & 4 & 46 & $\begin{array}{c}14 \\
4\end{array}$ & 55 & 4,00 \\
\hline
\end{tabular}

Tanggapan responden tentang variabel dimensi bukti fisik (tangible) rata-rata responden memberikan tanggapan cukup baik untuk setiap indikator. Ini berarti bahwa secara umum pegawai dan pengelola perguruan tinggi sudah memberi pelayanan yang terbaik bagi mahasiswa. Indikator yang relatif rendah berada pada kebersihan ruang kuliah yaitu sebesar 3,78.

Tabel 5.Tanggapan Responden Terhadap Variabel Daya Tanggap (Responsivennes).

\begin{tabular}{|c|c|c|c|c|c|c|c|c|}
\hline \multirow[b]{2}{*}{ No } & \multirow[b]{2}{*}{ Indikator } & \multirow{2}{*}{$\begin{array}{c}\text { Simbo } \\
1\end{array}$} & \multicolumn{5}{|c|}{ Tanggapan Responden } & \multirow[b]{2}{*}{ Rata-Rata } \\
\hline & & & $\begin{array}{l}\text { ST } \\
\text { B }\end{array}$ & $\mathrm{KB}$ & $\mathrm{CB}$ & B & $\mathrm{BS}$ & \\
\hline 1 & $\begin{array}{l}\text { Kesediaan penasehat } \\
\text { akademik dalam } \\
\text { melayani mahasiswa }\end{array}$ & $\mathrm{X} 21$ & 0 & 11 & 56 & $\begin{array}{c}14 \\
5\end{array}$ & 37 & 3,84 \\
\hline 2 & $\begin{array}{lr}\text { Kompetensi } & \text { dosen } \\
\text { dalam } & \text { menjawab } \\
\text { pertanyaan mahasiswa }\end{array}$ & $\mathrm{X} 22$ & 0 & 8 & 50 & $\begin{array}{c}15 \\
2\end{array}$ & 39 & 3,89 \\
\hline 3 & $\begin{array}{lr}\text { Karyawan } & \text { cepat } \\
\text { tanggap } & \text { melayani } \\
\text { mahasiswa } & \\
\end{array}$ & $\mathrm{X} 23$ & 3 & 1 & 38 & $\begin{array}{c}14 \\
7\end{array}$ & 60 & 4,04 \\
\hline 4 & $\begin{array}{l}\text { Karyawan cepat } \\
\text { tanggap menyelesaikan } \\
\text { keluhan mahasiswa }\end{array}$ & $\mathrm{X} 24$ & 6 & 25 & 69 & $\begin{array}{c}12 \\
5\end{array}$ & 24 & 3,55 \\
\hline 5 & $\begin{array}{l}\text { Kesigapan } \\
\text { karyawan/satpam dalam }\end{array}$ & $\mathrm{X} 25$ & 2 & 18 & 58 & $\begin{array}{c}15 \\
1\end{array}$ & 30 & 3,72 \\
\hline
\end{tabular}


mengatur tempat parkir

Tanggapan responden tentang variabel dimensi daya tanggap (responsiveness) rata-

rata responden memberikan tanggapan cukup baik untuk setiap indikator. Indikator yang relatif rendah berada pada karyawan cepat tanggap menyelesaikan keluhan mahasiswa yaitu sebesar 3,55. Hal ini berarti para pegawai dan pengelola perguruan tinggi lebih tanggap terhadap setiap keluhan dan permasalahan yang dihadapi oleh mahasiswa.

Tabel 6.Tanggapan Responden Terhadap Variabel Keterandalan (Reliability)

\begin{tabular}{|c|c|c|c|c|c|c|c|c|}
\hline \multirow[b]{2}{*}{ No } & \multirow[b]{2}{*}{ Indikator } & \multirow{2}{*}{$\begin{array}{c}\text { Simbo } \\
1\end{array}$} & \multicolumn{5}{|c|}{ Tanggapan Responden } & \multirow[t]{2}{*}{ Rata-Rata } \\
\hline & & & $\begin{array}{l}\text { ST } \\
\text { B }\end{array}$ & $\mathrm{KB}$ & $\mathrm{CB}$ & B & BS & \\
\hline 1 & $\begin{array}{l}\text { Prosedur pelayanan } \\
\text { yang cepat }\end{array}$ & X31 & 4 & 8 & 27 & $\begin{array}{c}15 \\
9\end{array}$ & 51 & 3,98 \\
\hline 2 & $\begin{array}{lr}\text { Penanganan } & \text { urusan } \\
\text { administrasi } & \text { dengan } \\
\text { cepat } & \\
\end{array}$ & X32 & 1 & 12 & 29 & $\begin{array}{c}16 \\
0\end{array}$ & 47 & 3,96 \\
\hline
\end{tabular}

Tanggapan responden tentang variabel dimensi keterandalan (reliability) rata-rata responden memberikan tanggapan cukup baik untuk setiap indikator. Hal ini menunjukkan bahwa para pegawai dan pengelola perguruan tinggi memberikan pelayanan yang memuaskan dan tanggap setiap keluhan dan permasalahan yang dihadapi oleh mahasiswa.

Tabel 7. Tanggapan Responden Terhadap Variabel Empati (Emphaty).

\begin{tabular}{|c|c|c|c|c|c|c|c|c|}
\hline \multirow[b]{2}{*}{ No } & \multirow[b]{2}{*}{ Indikator } & \multirow{2}{*}{$\begin{array}{c}\text { Simbo } \\
1\end{array}$} & \multicolumn{5}{|c|}{ Tanggapan Responden } & \multirow[t]{2}{*}{ Rata-Rata } \\
\hline & & & $\begin{array}{l}\text { ST } \\
\text { B }\end{array}$ & $\mathrm{KB}$ & $\mathrm{CB}$ & B & BS & \\
\hline 1 & $\begin{array}{lr}\text { Memberikan } & \text { perhatian } \\
\text { khusus } & \text { kepada } \\
\text { mahasiswa } & \text { yang } \\
\text { bermasalah } & \end{array}$ & $\mathrm{X} 41$ & 1 & 2 & 31 & $\begin{array}{c}14 \\
7\end{array}$ & 68 & 4,12 \\
\hline 2 & $\begin{array}{l}\text { Masa pendidikan yang } \\
\text { terkontrol }\end{array}$ & $\mathrm{X} 42$ & 2 & 9 & 48 & $\begin{array}{c}13 \\
5\end{array}$ & 55 & 3,93 \\
\hline
\end{tabular}

Tanggapan responden tentang variabel dimensi empati (emphaty) rata-rata

responden memberikan tanggapan cukup baik untuk setiap indikator. Hal ini menunjukkan bahwa para pegawai dan pengelola perguruan tinggi telah memberikan perhatian khusus kepada mahasiswa yang bermasalah, pemberian rasa aman dan nyaman kepada mahasiswa di lingkungan kampus sehingga mahasiswa mampu menyelesaikan studi tepat waktu.

Tabel 8.Tanggapan Responden Terhadap Variabel Jaminan (Assurance).

\begin{tabular}{|c|c|c|c|c|c|c|c|c|}
\hline \multirow{2}{*}{ No } & Indikator & $\begin{array}{c}\text { Simbo } \\
1\end{array}$ & $\begin{array}{c}\text { ST } \\
\text { B }\end{array}$ & KB & CB & B & BS & Rata-Rata \\
\hline 1 & $\begin{array}{l}\text { Kemampuan para dosen } \\
\text { dalam menyampaikan } \\
\text { materi perkuliahan }\end{array}$ & X51 & 0 & 2 & 46 & $\begin{array}{c}14 \\
8\end{array}$ & 53 & 4,01 \\
\hline 2 & Keterampilan pegawai & X52 & 0 & 1 & 51 & 14 & 51 & 3,99 \\
\hline
\end{tabular}




\begin{tabular}{|c|c|c|c|c|c|c|c|c|}
\hline & $\begin{array}{l}\text { administrasi dalam } \\
\text { bekerja }\end{array}$ & & & & & 6 & & \\
\hline 3 & $\begin{array}{lr}\begin{array}{l}\text { Keramahan para } \\
\text { karyawan } \\
\text { memberikan pelayanan } \\
\text { dalam }\end{array} \\
\end{array}$ & X53 & 0 & 5 & 51 & $\begin{array}{c}14 \\
2\end{array}$ & 51 & 3,96 \\
\hline 4 & $\begin{array}{lr}\text { Sikap para karyawan } \\
\text { dalam } & \text { memberikan } \\
\text { pelayanan } & \\
\end{array}$ & X54 & 0 & 5 & 36 & $\begin{array}{c}16 \\
3\end{array}$ & 45 & 4,00 \\
\hline 5 & $\begin{array}{l}\text { Jaminan nilai UTS tepat } \\
\text { waktu }\end{array}$ & X55 & 0 & 2 & 30 & $\begin{array}{c}16 \\
0 \\
\end{array}$ & 57 & 4,09 \\
\hline 6 & $\begin{array}{lcr}\text { Pemberian } & \text { ujian her } \\
\text { (ujian } & \text { mengulang/ } \\
\text { susulan) } & \text { yang tepat } \\
\text { waktu } & & \\
\end{array}$ & X56 & 0 & 1 & 36 & $\begin{array}{c}15 \\
8\end{array}$ & 54 & 4,06 \\
\hline 7 & $\begin{array}{l}\text { Ketepatan waktu dosen } \\
\text { mengajar di kelas }\end{array}$ & X57 & 0 & 2 & 38 & $\begin{array}{c}15 \\
7\end{array}$ & 52 & 4,04 \\
\hline 8 & $\begin{array}{l}\text { Ketepatan dalam } \\
\text { disiplin perkuliahan }\end{array}$ & X58 & 1 & 8 & 36 & $\begin{array}{c}15 \\
2 \\
\end{array}$ & 52 & 3,99 \\
\hline
\end{tabular}

Tanggapan responden tentang variabel dimensi jaminan (assurance) rata-rata responden memberikan tanggapan cukup baik untuk setiap indikator. Jaminan nilai UTS tepat waktu menunjukkan nilai tertinggi, sedangkan keramahan para karyawan dalam memberikan pelayanan mendapatkan penilaian terendah.

\section{Variabel Laten Kepuasan Mahasiswa.}

Kepuasan pelanggan sangat tergantung pada kualitas produk atau layanan jasa yang diperolehnya. Kualitas layanan mencerminkan perbandingan antara tingkat layanan yang disampaikan penyedia jasa dibandingkan dengan harapan/ekspektasi pelanggan. Jadi, suatu produk atau layanan jasa berkualitas bagi seseorang diwujudkan melalui pemenuhan kebutuhan dan keinginan pelanggan sesuai dengan harapannya. Sarana dan prasarana dalam dunia pendidikan tinggi sangat berpengaruh terhadap kepuasan mahasiswa sebagai konsumen atau pelanggan. Jika kualitas layanan dalam dunia pendidikan tidak memenuhi harapan konsumen atau pelanggan, maka perkembangan perguruan tinggi tersebut ke depannya akan sulit berkembang. Oleh karena itu diperlukan perbaikan-perbaikan dalam hal kualitas layanan yang diberikan oleh pegawai dan pengelola perguruan tinggi.

Tabel 9 Tanggapan Responden Terhadap Variabel Kognisi. 


\begin{tabular}{|c|l|c|c|c|c|c|c|c|}
\hline \multirow{2}{*}{ No } & \multicolumn{1}{|c|}{ Indikator } & \multirow{2}{*}{$\begin{array}{c}\text { Simbo } \\
1\end{array}$} & $\begin{array}{c}\text { ST } \\
\text { B }\end{array}$ & KB & CB & B & BS & Rata-Rata \\
\hline 1 & Pengetahuan & Y11 & 4 & 21 & 41 & $\begin{array}{c}13 \\
9\end{array}$ & 44 & 3,80 \\
\hline 2 & Penguasaan & Y12 & 2 & 28 & 45 & $\begin{array}{c}13 \\
0\end{array}$ & 44 & 3,75 \\
\hline 3 & Pemahaman & Y13 & 2 & 12 & 47 & $\begin{array}{c}15 \\
3\end{array}$ & 35 & 3,83 \\
\hline
\end{tabular}

Tanggapan responden tentang variabel dimensi kognisi rata-rata responden memberikan tanggapan cukup baik untuk setiap indikator. Dimensi kognisi mencakup pengetahuan, penguasaan dan pemahaman mahasiswa setelah mengikuti proses pembelajaran. Hal ini menunjukkan bahwa perguruan tinggi memiliki dosen-dosen yang mempunyai kompentesi sesuai dengan harapan mahasiswa, sehingga mahasiswa dapat dengan mudah memahami materi perkuliahan yang disampaikan oleh dosen.

Tabel 10.Tanggapan Responden Terhadap Variabel Afeksi.

\begin{tabular}{|c|c|c|c|c|c|c|c|c|}
\hline \multirow[b]{2}{*}{ No } & \multirow[b]{2}{*}{ Indikator } & \multirow[b]{2}{*}{$\begin{array}{c}\text { Simbo } \\
1\end{array}$} & \multicolumn{5}{|c|}{ Tanggapan Responden } & \multirow[t]{2}{*}{ Rata-Rata } \\
\hline & & & $\begin{array}{c}\text { ST } \\
\text { B }\end{array}$ & $\mathrm{KB}$ & $\mathrm{CB}$ & $\mathrm{B}$ & $\mathrm{BS}$ & \\
\hline 1 & Sikap & Y21 & 1 & 3 & 53 & $\begin{array}{c}15 \\
1\end{array}$ & 41 & 3,92 \\
\hline 2 & Aspirasi & Y22 & 1 & 2 & 55 & $\begin{array}{c}14 \\
3\end{array}$ & 48 & 3,94 \\
\hline 3 & Perasaan & Y23 & 3 & 19 & 59 & $\begin{array}{c}14 \\
0\end{array}$ & 28 & 3,69 \\
\hline 4 & Dorongan/Motivasi & Y24 & 2 & 6 & 69 & $\begin{array}{c}13 \\
7\end{array}$ & 35 & 3,79 \\
\hline 5 & Nilai-Nilai & Y25 & 1 & 7 & 67 & $\begin{array}{c}13 \\
8\end{array}$ & 36 & 3,81 \\
\hline
\end{tabular}

Tanggapan responden tentang dimensi afeksi rata-rata responden memberikan tanggapan cukup baik untuk setiap indikator. Dimensi afeksi mencakup sikap, aspirasi, perasaan, dorongan/motivasi, dan nilai-nilai. Hal ini menunjukkan bahwa dimensi afeksi secara rata-rata telah cukup baik. Hal ini menunjukkan bahwa perguruan tinggi dapat memenuhi kepuasan mahasiswa sesuai dengan kualitas layanan yang diberikan.

Tabel 11.Tanggapan Responden Terhadap Variabel Psikomotor.

\begin{tabular}{|l|l|l|l|l|}
\hline No & Indikator & Simbo & Tanggapan Responden & Rata-Rata \\
\hline
\end{tabular}




\begin{tabular}{|c|l|c|c|c|c|c|c|c|}
\hline & & 1 & $\begin{array}{c}\text { ST } \\
\text { B }\end{array}$ & KB & CB & B & BS & \\
\hline 1 & Kemampuan teknik & Y31 & 2 & 8 & 68 & $\begin{array}{c}13 \\
8\end{array}$ & 33 & 3,77 \\
\hline 2 & Kemampuan sosial & Y32 & 2 & 10 & 46 & $\begin{array}{c}15 \\
1\end{array}$ & 40 & 3,87 \\
\hline 3 & Kemampuan manajerial & Y33 & 0 & 16 & 50 & $\begin{array}{c}14 \\
8\end{array}$ & 35 & 3,81 \\
\hline 4 & Kemampuan intelektual & Y34 & 0 & 12 & 45 & $\begin{array}{c}15 \\
6\end{array}$ & 36 & 3,87 \\
\hline 5 & Kemampuan emosional & Y35 & 0 & 6 & 39 & $\begin{array}{c}16 \\
7\end{array}$ & 37 & 3,94 \\
\hline 6 & Kemampuan spiritual & Y36 & 0 & 6 & 38 & $\begin{array}{c}16 \\
0\end{array}$ & 45 & 3,98 \\
\hline
\end{tabular}

Tanggapan responden tentang dimensi psikomotor rata-rata responden memberikan tanggapan cukup baik untuk setiap indikator. Dimensi psikomotor mencakup kemampuan teknik, sosial, manajerial, intelektual, emosional, dan spiritual. Hal ini menunjukkan bahwa dimensi psikomotor secara rata-rata lebih baik dibandingkan dengan dimensi kognisi dan afeksi.

\section{ANALISIS MODEL STRUKTURAL}

Analisis model struktural terbagi dalam dua tahap, yaitu analisis model pengukuran dan model persamaan struktural. Untuk memperoleh hasil model struktural yang baik sangat ditentukan oleh hasil analisis model pengukuran.

\section{Model Pengukuran $2^{\text {nd }}$ Confirmatory Faktor Analysis.}

Analisa model pengukuran $2^{\text {nd }}$ second confirmatory faktor analysis (CFA) merupakan tahap pengukuran terhadap dimensi-dimensi dilakukan secara terpisah untuk konstruk-konstruk eksogen dan konstruk-konstruk endogen. Berujuan untuk memastikan variabel teramati yang ditentukan secara teoritis merupakan indikator yang valid pada masing-masing variabel laten dalam model penelitian, sebagai berikut:

Tabel 12. Variabel Laten dan Dimensi

\begin{tabular}{|c|c|l|c|}
\hline Variabel Laten & Simbol Variabel Laten & \multicolumn{1}{|c|}{ Dimensi } & Simbol Dimensi \\
\hline Kualitas Layanan & $\xi_{1}$ & 1. Tangible & X1 \\
Pendidikan & & 2. Responsiveness & X2 \\
(KLP) & & 3. Reliability & X3 \\
& & 4. Emphaty & X4 \\
& & 5. Assurance & X5 \\
\hline Kepuasan Mahasiswa & \multirow{2}{*}{ (KM) } & 1. Kognisi & Y1 \\
& & 2. Afektif & Y3 \\
\hline
\end{tabular}

Sumber : Data diolah, 2017.

Berdasarkan hasil evaluasi terhadap model pengukuran dimensi konstruk dapat 
dijelaskan sebagai berikut :

\section{Confirmatory Faktor Analysis Kualitas Layanan Pendidikan.}

Konstruk variabel laten eksogen kualitas layanan pendidikan merupakan model pengukuran $2^{\text {nd }}$ CFA terdiri dari 5 dimensi atau second order, yaitu Tangible (X1), Responsiveness (X2), Reliability (X3), Emphaty (X4), dan Assurance (X5). Dimensi Tangible (X1) yang merupakan first order diukur oleh 7 parameter variabel teramati (X11$\mathrm{X} 17)$. Dimensi Responsiveness (X2) diukur oleh 5 parameter variabel teramati (X21-X25). Dimensi Reliability (X3) diukur oleh 2 parameter variabel teramati (X31-X32). Dimensi Emphaty (X4) diukur oleh 2 parameter variabel teramati (X41-X42), dan Dimensi Assurance (X5) diukur oleh 8 parameter variabel teramati (X51-X58). Model pengukuran $2^{\text {nd }} \mathrm{CFA}$ terhadap konstruk variabel laten eksogen kualitas layanan pendidikan sebagaimana terlihat pada gambar berikut ini.

Gambar 3. Diagram Lintasan Model Pengukuran $2^{\text {nd }}$ CFA Konstruk Variabel Laten Eksogen Kualitas Layanan Pendidikan (Standardized Solution)

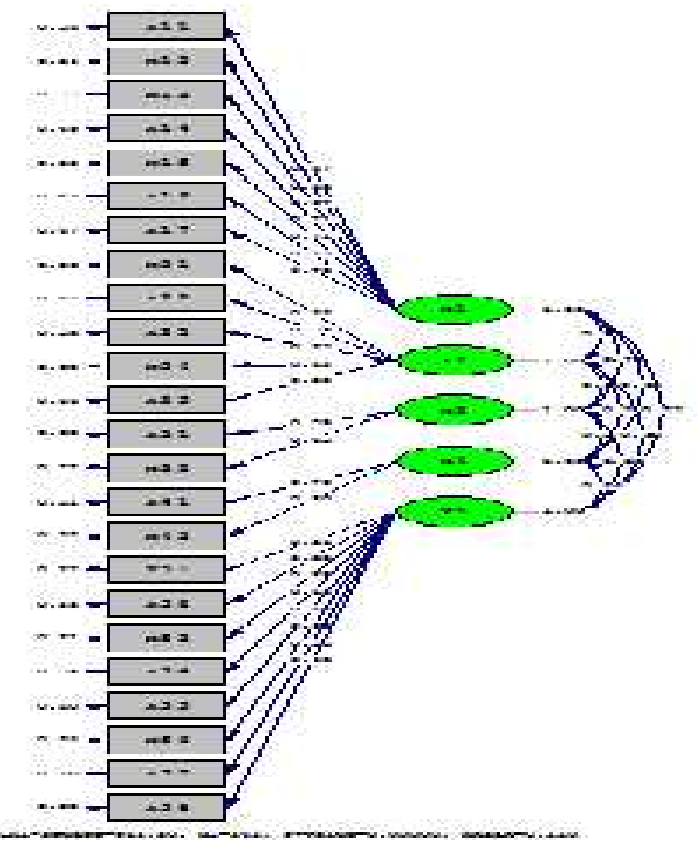

Dari gambar 3 diagram lintasan diatas, dapat dilihat bahwa variabel teramati (X58 $=0.43$ ) menunjukkan validitas kurang baik dan tidak memenuhi persyaratan (SLF $\geq 0.50$ ). Oleh karena itu, variabel teramati $(\mathrm{X} 58=0.43)$ dikeluarkan dari model dan diestimasi ulang, sehingga diperoleh diagram lintasan model pengukuran $2^{\text {nd }}$ confirmatory faktor analysis yang memenuhi persyaratan yang ditetapkan sebagaimana uraian berikut ini.

\section{Model Pengukuran Parameter Konstruk Kualitas Layanan Pendidikan.}


Berdasarkan gambar 3 diatas, dimensi Tangible (X1) nilai parameter variabel teramati $\left(\lambda_{11}\right) 0.72$, nilai parameter variabel teramati $\left(\lambda_{12}\right) 0.67$, nilai parameter variabel teramati $\left(\lambda_{13}\right) 0.64$, nilai parameter variabel teramati $\left(\lambda_{14}\right) 0.73$, nilai parameter variabel teramati $\left(\lambda_{15}\right) 0.67$, nilai parameter variabel teramati $\left(\lambda_{16}\right) 0.66$, dan nilai parameter variabel teramati $\left(\lambda_{17}\right)$ 0.74. Dengan demikian dapat disimpulkan bahwa indikator dari dimensi Tangible (X1) yang memberi kontribusi terbesar terbentuknya konstruk kualitas layanan pendidikan adalah nilai parameter variabel teramati $\left(\lambda_{17}\right)$ sebesar 0.74 . Dimensi Responsiveness (X2) nilai parameter variabel teramati $\left(\lambda_{21}\right) 0.61$, nilai parameter variabel teramati $\left(\lambda_{22}\right) 0.53$, nilai parameter variabel teramati $\left(\lambda_{23}\right) 0.61$, nilai parameter variabel teramati $\left(\lambda_{24}\right) 0.57$, nilai parameter variabel teramati $\left(\lambda_{25}\right) 0.55$. Dengan demikian dapat disimpulkan bahwa indikator dari dimensi Responsiveness (X2) yang memberi kontribusi terbesar terbentuknya konstruk kualitas layanan pendidikan adalah nilai parameter variabel teramati $\left(\lambda_{21}\right)$ dan $\left(\lambda_{23}\right)$ sebesar 0.61 .

Dimensi Reliability (X3) nilai parameter variabel teramati $\left(\lambda_{31}\right) 0.58$, dan nilai parameter variabel teramati $\left(\lambda_{32}\right)$ 0.66. Dengan demikian dapat disimpulkan bahwa indikator dari dimensi Reliability (X3) yang memberi kontribusi terbesar terbentuknya konstruk kualitas layanan pendidikan adalah nilai parameter variabel teramati $\left(\lambda_{32}\right)$ sebesar 0.66. Dimensi Emphaty (X4) nilai parameter variabel teramati $\left(\lambda_{41}\right) 0.68$ dan nilai parameter variabel teramati $\left(\lambda_{42}\right)$ 0.81. Dengan demikian dapat disimpulkan bahwa indikator dari dimensi Emphaty (X4) yang memberi kontribusi terbesar terbentuknya konstruk kualitas layanan pendidikan adalah nilai parameter variabel teramati $\left(\lambda_{42}\right)$ sebesar 0.81. Dimensi Assurance (X5) nilai parameter variabel teramati $\left(\lambda_{51}\right) 0.78$, nilai parameter variabel teramati $\left(\lambda_{52}\right) 0.70$, nilai parameter variabel teramati $\left(\lambda_{53}\right) 0.78$, nilai parameter variabel teramati $\left(\lambda_{54}\right) 0.69$, nilai parameter variabel teramati $\left(\lambda_{55}\right) 0.68$, nilai parameter variabel teramati $\left(\lambda_{56}\right) 0.63$, dan nilai parameter variabel teramati $\left(\lambda_{57}\right) 0.57$. Dengan demikian dapat disimpulkan bahwa indikator dari dimensi Assurance (X5) yang memberi kontribusi terbesar terbentuknya konstruk kualitas layanan pendidikan adalah nilai parameter variabel teramati $\left(\lambda_{51}\right)$ dan $\left(\lambda_{53}\right)$ sebesar 0.78 .

\section{Evaluasi Kecocokan Model Kualitas Layanan Pendidikan}


Hasil modifikasi model pengukuran $2^{\text {nd }}$ CFA diperoleh nilai goodness of fit index dari model pengukuran $2^{\text {nd }} \mathrm{CFA}$ variabel kualitas layanan pendidikan yang telah memenuhi kelayakan sebuah model seperti terlihat pada tabel berikut ini.

Tabel 13. Goodness of Fit Index (GOFI) Model Pengukuran Konstruk Eksogen Kualitas Layanan Pendidikan

\begin{tabular}{|l|c|ll|l|}
\hline \multicolumn{1}{|c|}{ Ukuran GOFI } & Nilai Hasil & \multicolumn{2}{|c|}{ Nilai Standar } & Kesimpulan \\
\hline p-value & 0.68 & p-value $\geq 0.05$ & Kecocokan Baik \\
RMSEA & 0.00 & RMSEA $\leq 0.08$ & Kecocokan Baik \\
NFI & 0.99 & NFI & $\geq 0.90$ & Kecocokan Baik \\
NNFI & 1.00 & NNFI & $\geq 0.90$ & Kecocokan Baik \\
CFI & 1.00 & CFI & $\geq 0.90$ & Kecocokan Baik \\
IFI & 1.00 & IFI & $\geq 0.90$ & Kecocokan Baik \\
RFI & 0.97 & RFI & $\geq 0.90$ & Kecocokan Baik \\
SRMR & 0.02 & SRMR & $\leq 0.05$ & Kecocokan Baik \\
GFI & 0.95 & GFI & $\geq 0.90$ & Kecocokan Baik \\
AGFI & 0.91 & AGFI & $\geq 0.90$ & Kecocokan Baik \\
\hline
\end{tabular}

\section{Evaluasi Terhadap Validitas, Reliabilitas dan Variance Extracted.}

Prosedur yang dilakukan untuk mengukur reliabilitas dan validitas data, yaitu : (1) Uji konsistensi internal (reliabilitas), (2) Uji validitas konstruk berkaitan dengan tingkat skor. standardized loading factors (SLF) dikatakan valid bila SLF > 0.50. Sedangkan reliabilitas dikatakan baik, jika construct reliability $(\mathrm{CR})>0.70$ dan variance extracted $(\mathrm{VE})>0.50$. Adapun hasil perhitungan construct reliability dan variance extracted adalah sebagai berikut:

Tabel 14. Uji Validitas, Reliabilitas, dan Variance Extracted

\begin{tabular}{|c|c|c|c|l|l|}
\hline Variabel & *SLF \0.5 & Error & *CR \0.6 & $*$ VE $\searrow \mathbf{0 . 5}$ & \multicolumn{1}{|c|}{ Kesimpulan } \\
\hline X1 & & & 0.92 & 0.64 & Reliabilitas baik \\
X11 & 0.72 & 0.28 & & & Validitas baik \\
X12 & 0.67 & 0.33 & & Validitas baik \\
X13 & 0.64 & 0.36 & & Validitas baik \\
X14 & 0.73 & 0.27 & & Validitas baik \\
X15 & 0.67 & 0.33 & & & Validitas baik \\
X16 & 0.66 & 0.34 & & & Validitas baik \\
X17 & 0.74 & 0.26 & & & Validitas baik \\
X2 & & & 0.79 & 0.53 & Reliabilitas Baik \\
X21 & 0.61 & 0.39 & & & Validitas baik \\
\hline
\end{tabular}




\begin{tabular}{|c|c|c|c|c|c|}
\hline $\mathrm{X} 22$ & 0.53 & 0.47 & & & Validitas baik \\
\hline $\mathrm{X} 23$ & 0.61 & 0.39 & & & Validitas baik \\
\hline $\mathrm{X} 24$ & 0.57 & 0.43 & & & Validitas baik \\
\hline $\mathrm{X} 25$ & 0.55 & 0.45 & & & Validitas baik \\
\hline $\mathrm{X} 3$ & & & 0.67 & 0.50 & Reliabilitas Baik \\
\hline X31 & 0.58 & 0.42 & & & Validitas baik \\
\hline $\mathrm{X} 32$ & 0.66 & 0.34 & & & Validitas baik \\
\hline $\mathrm{X} 4$ & & & 0.81 & 0.69 & Reliabilitas Baik \\
\hline $\mathrm{X} 41$ & 0.68 & 0.32 & & & Validitas baik \\
\hline $\mathrm{X} 42$ & 0.81 & 0.19 & & & Validitas baik \\
\hline $\mathrm{X} 5$ & & & 0.91 & 0.61 & Reliabilitas baik \\
\hline $\mathrm{X} 51$ & 0.78 & 0.22 & & & Validitas baik \\
\hline X52 & 0.70 & 0.30 & & & Validitas baik \\
\hline X53 & 0.78 & 0.22 & & & Validitas baik \\
\hline X54 & 0.69 & 0.31 & & & Validitas baik \\
\hline X55 & 0.68 & 0.32 & & & Validitas baik \\
\hline $\mathrm{X} 56$ & 0.63 & 0.37 & & & Validitas baik \\
\hline $\mathrm{X} 57$ & 0.57 & 0.43 & & & Validitas baik \\
\hline
\end{tabular}

* SLF = Standardized Loading Factor $\quad * \mathrm{CR} \quad=$ Construct Reliability;

* VE = Variance Extracted

Berdasarkan tabel 14.tersebut diatas memperlihatkan bahwa seluruh parameter variabel teramati dapat dikatakan validitas baik, karena nilai standardized loading factor $(\mathrm{SLF})>0.50$. Demikian juga dengan nilai $\mathrm{CR}$ dari model pengukuran $>0.70$ dan nilai VE $>0.50$, yang berarti reliabilitas model pengukuran variabel laten compliance adalah baik.

\section{Confirmatory Faktor Analysis Variabel Laten Kepuasan Mahasiswa.}

Konstruk variabel laten endogen kepuasan mahasiswa merupakan model pengukuran $2^{\text {nd }} \mathrm{CFA}$ terdiri dari 3 dimensi atau second order, yaitu Kognisi (Y1), Afeksi (Y2), dan Psikomotor (Y3). Dimensi Kognisi (Y1) yang merupakan first order diukur oleh 3 parameter variabel teramati (Y11-Y13). Dimensi Afeksi (Y2) diukur oleh 5 parameter variabel teramati (Y21-Y25). Dimensi Psikomotor (Y3) diukur oleh 6 parameter variabel teramati (Y31-Y36). Model pengukuran $2{ }^{\text {nd }} \mathrm{CFA}$ terhadap konstruk variabel laten endogen kepuasan mahasiswa sebagai berikut:

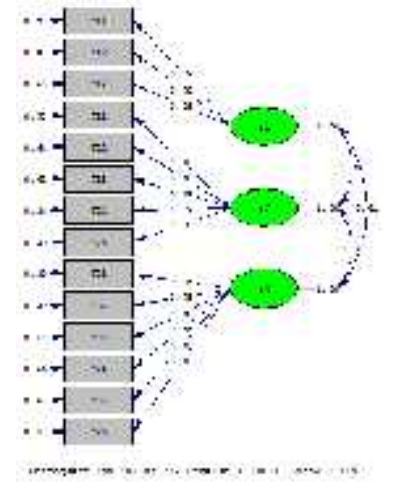

Gambar 4. Diagram Lintasan Model Pengukuran $2^{\text {nd }}$ CFA Konstruk Variabel Laten Endogen Kepuasan Mahasiswa (Standardized Solution) 
Dari gambar 4 diagram lintasan di atas, dapat dilihat bahwa seluruh nilai parameter variabel teramati menunjukkan validitas baik dan memenuhi persyaratan ( $\mathrm{SLF} \geq 0.50$ ). Model pengukuran $2^{\text {nd }}$ confirmatory faktor analysis yang memenuhi persyaratan yang ditetapkan sebagaimana uraian berikut:

Model Pengukuran Parameter Konstruk Kepuasan Mahasiswa.

Berdasarkan gambar terbut diatas, dimensi Kognisi (Y1) nilai parameter variabel teramati $\left(\lambda_{61}\right) 0.50$, nilai parameter variabel teramati $\left(\lambda_{62}\right) 0.50$, nilai parameter variabel teramati $\left(\lambda_{63}\right)$ 0.82. Dengan demikian dapat disimpulkan bahwa indikator dari dimensi Kognisi (Y1 yang memberi kontribusi terbesar terbentuknya konstruk kepuasan adalah nilai parameter variabel teramati $\left(\lambda_{63}\right)$ sebesar 0.82. Dimensi Afeksi (Y2) nilai parameter variabel teramati $\left(\lambda_{71}\right) 0.68$, nilai parameter variabel teramati $\left(\lambda_{72}\right) 0.59$, nilai parameter variabel teramati $\left(\lambda_{73}\right) 0.62$, nilai parameter variabel teramati $\left(\lambda_{74}\right) 0.73$, nilai parameter variabel teramati $\left(\lambda_{75}\right)$ 0.68. Dengan demikian dapat disimpulkan bahwa indikator dari dimensi Afeksi (Y2) yang memberi kontribusi terbesar terbentuknya konstruk kepuasan mahasiswa adalah nilai parameter variabel teramati $\left(\lambda_{74}\right)$ sebesar 0.73. Dimensi Psikomotor (Y3) nilai parameter variabel teramati $\left(\lambda_{81}\right) 0.67$, nilai parameter variabel teramati $\left(\lambda_{82}\right) 0.70$, nilai parameter variabel teramati $\left(\lambda_{83}\right) 0.65$, nilai parameter variabel teramati $\left(\lambda_{84}\right) 0.58$, nilai parameter variabel teramati $\left(\lambda_{85}\right) 0.71$, dan nilai parameter variabel teramati $\left(\lambda_{86}\right)$ 0.68. Dengan demikian dapat disimpulkan bahwa indikator dari dimensi Psikomotor (Y3) yang memberi kontribusi terbesar terbentuknya konstruk kepuasan mahasiswa adalah nilai parameter variabel teramati $\left(\lambda_{85}\right)$ sebesar 0.71 .

\section{Evaluasi Kecocokan Model Kepuasan Mahasiswa.}

Hasil modifikasi model pengukuran $2^{\text {nd }}$ CFA diperoleh nilai goodness of fit index dari model pengukuran $2^{\text {nd }} \mathrm{CFA}$ variabel kepuasan mahasiswa yang telah memenuhi kelayakan sebuah model seperti terlihat pada tabel berikut ini. 
Tabel 15. Goodness of Fit Index (GOFI) Model Pengukuran Konstruk Endogen

Kepuasan Mahasiswa.

\begin{tabular}{|c|c|c|c|c|}
\hline Ukuran GOFI & Nilai Hasil & \multicolumn{2}{|c|}{ Nilai Standar } & Kesimpulan \\
\hline $\mathrm{p}$-value & 0.73 & p-value & $\geq 0.05$ & Kecocokan Baik \\
\hline RMSEA & 0.00 & RMSEA & $\leq 0.08$ & Kecocokan Baik \\
\hline NFI & 0.99 & NFI & $\geq 0.90$ & Kecocokan Baik \\
\hline NNFI & 1.00 & NNFI & $\geq 0.90$ & Kecocokan Baik \\
\hline CFI & 1.00 & CFI & $\geq 0.90$ & Kecocokan Baik \\
\hline IFI & 1.00 & IFI & $\geq 0.90$ & Kecocokan Baik \\
\hline RFI & 0.98 & RFI & $\geq 0.90$ & Kecocokan Baik \\
\hline SRMR & 0.02 & SRMR & $\leq 0.05$ & Kecocokan Baik \\
\hline GFI & 0.98 & GFI & $\geq 0.90$ & Kecocokan Baik \\
\hline AGFI & 0.95 & AGFI & $\geq 0.90$ & Kecocokan Baik \\
\hline
\end{tabular}

\section{KESIMPULAN}

Deskripsi variabel konstruk kualitas layanan pendidikan menunjukkan sebagian besar mahasiswa atau responden mempunyai persepsi bahwa kualitas layanan pendidikan secara keseluruhan menyatakan baik. Berdasarkan item masing-masing indikator terlihat bahwa dari; a) Indikator bukti fisik (tangible) menunjukkan kebersihan ruang kuliah mendapatkan penilaian terendah sedangkan kerapihan ruang kuliah menunjukkan nilai tertinggi; b) Indikator daya tanggap (responsiveness) menunjukkan karyawan cepat tanggap menyelesaikan keluhan mahasiswa menunjukkan nilai terendah, sedangkan karyawan cepat tanggap melayani mahasiswa mendapatkan nilai tertinggi; c) Indikator keterandalan (reliability) menunjukkan penanganan administrasi dengan cepat menunjukkan nilai terendah, sedangkan prosedur pelayanan yang cepat mendapatkan nilai tertinggi; d) Indikator empati (emphaty) masa pendidikan yang terkontrol menunjukkan nilai terendah, sedangkan item memberikan perhatian khusus kepada mahasiswa yang bermasalah mendapatkan nilai tertinggi; e) Indikator jaminan (assurance) menunjukkan bahwa keramahan para karyawan dalam memberikan pelayanan mendapatkan nilai terendah, sedangkan jaminan nilai UTS tepat waktu mendapatkan nilai tertinggi.

Deskripsi kepuasan mahasiswa setelah mengikuti pendidikan; a) Dilihat dari indikator kognisi menunjukkan bahwa tingkat kepuasan mahasiswa setelah mengikuti proses pendidikan mendapatkan penilaian tertinggi pada item pengetahuan dan pemahaman; b) Dilihat dari indikator afeksi menunjukkan bahwa tingkat kepuasan mahasiswa setelah mengikuti pendidikan mendapatkan penilaian tertinggi pada item sikap dan aspirasi; c) Dilihat dari indikator psikomotor menunjukkan bahwa tingkat kepuasan 
mahasiswa setelah mengikuti pendidikan mendapatkan penilaian tertinggi pada item kemampuan emosional dan kemampuan spiritual.

Berdasarkan modifikasi model beberapa dimensi/indikator goodness of fit (kesesuaian, kecocokan) sangat baik, sehingga model teoritis sesuai dengan data empiris. Dengan demikian hubungan antar variabel dapat disimpulkan sebagai berikut; a) Variabel laten kualitas layanan pendidikan diukur dengan dimensi/indikator tangible, responsiveness, reliability, emphaty, assurance dan variabel laten kepuasan mahasiswa diukur dengan kognisi, afeksi, dan psikomotor terbukti secara nyata mengukur variabel laten kualitas layanan pendidikan dan kepuasan mahasiswa; b) Berdasarkan estimasi uji hipotesis menunjukkan bahwa variabel konstruk kualitas layanan pendidikan mempunyai pengaruh positif dan signifikan terhadap kepuasan mahasiswa. Hasil penelitian ini memiliki implikasi kebijakan dan mengindikasikan diperlukannya perbaikan dalam hal kebersihan ruang kuliah, menyelesaikan keluhan mahasiswa, penanganan administrasi dengan cepat, perhatian dengan masa pendidikan yang terkontrol, dan keramahan karyawan dalam memberikan pelayanan.

\section{DAFTAR PUSTAKA}

Aziz, Safrudin. 2016. Manajemen Mutu Perguruan Tinggi-Koreksi dan Implementasi.Cetakan I. Yogyakarta: Gava Media.

Fikri, S. Wiyani, W dan Suwandaru, A. 2016. Pengaruh Kualitas Pelayanan Terhadap Kepuasan Dan Loyalitas Mahasiswa (Studi pada Mahasiswa Strata I Fakultas Ilmu Sosial dan Ilmu Politik Universitas Merdeka Malang). Jurnal Bisnis dan Manajemen Vol. 3 No. 1, Januari 2016.

Kotler, Philip \& Keller, Kevin Lane. 2007. Manajemen Pemasaran. Edisi Bahasa Indonesia. Edisi 12. Jakarta: Indeks.

Kotler, Philip \& Amstrong, Gary. 2008. Prinsip-Prinsip Pemasaran. Edisi ke 12. Jakarta: Erlangga.

Kusdiyantoro, S. 2014. Pengaruh Kualitas Layanan Terhadap Kepuasan Mahasiswa Program Pascasarjana Magister Manajemen STIE ABI Surabaya. 2014. Jurnal Bisnis, Manajemen \& Perbankan Vol.1 No.2 September 2014.

Nazir, M. 2014. Metode Penelitian.Cetakan kesembilan. Bogor: Ghalia Indonesia. Rama Putra Barusman, Andala. 2014. Anteseden Dan Konsekuensi Dari Student Satisfaction Pada Universitas Swasta.

Sugiyono. 2012. Statistika Untuk Penelitian. Cetakan ke 21.Bandung: Alfabeta.

Sugiyono. 2001. Metode Penelitian Bisnis. Cetakan ketiga. Bandung: Alfabeta. 
Susanto, H. 2014. Pengaruh Layanan Akademik Terhadap Kepuasan Mahasiswa Program Pascasarjana Universitas Terbuka Pada Unit Program Belajar Jarak Jauh (UPBJJ) Mataram. Jurnal Pendidikan Terbuka dan Jarak jauh, Volume 15, Nomer 2, September 2014.

Samosir, Z.Z.2005.Pengaruh Kualitas Pelayanan Terhadap Kepuasan Mahasiswa Menggunakan Perpustakaan USU. Jurnal Studi Perpustakaan dan Informasi, Vol. 1, No. 1, Juni 2005.

Tjiptono, Fandy dan Diana, Anastasia. 2003. Total Quality Management. Yogyakarta: Andi Offset.

Tjiptono, Fandy \& Chandra, Gregorius. 2012. Pemasaran Strategik. Edisi 2. Yogyakarta: Andi Offset.

Tjiptono, Fandy. 2014. Pemasaran Jasa - Prinsip, Penerapan, dan Penelitian. Yogyakarta: Andi Offset

Tampubolon.1997. Strategi Pengelolaan dan Peningkatan Kualitas Perguruan Tinggi. Semiloka Nasional, Yogyakarta: Kopertis Wilayah V Daerah Istimewa Yogyakarta.

Wijaya, David. 2012. Pemasaran Jasa Pendidikan. Jakarta: Salemba Empat.

Yuniarti, Y. 2014. Pengaruh Kualitas Pelayanan Terhadap Kepuasan Mahasiswa Program Ekstensi Fakultas Ekonomi Universitas Jambi.Jurnal Trikonomika Volume 13, No. 1, Juni 2014. 